\title{
Colchicine derivatives inhibit neopterin production in human peripheral blood mononuclear cells (PBMC)
}

\author{
Z. Z. ALTINDAG*, G. WERNER-FELMAYER, G. SAHIN*, H. WACHTER \& D. FUCHS Institute for Medical \\ Chemistry and Biochemistry, University of Innsbruck and Ludwig Boltzmann Institute of AIDS Research, Innsbruck, Austria, and \\ *Department of Pharmaceutical Toxicology, Faculty of Pharmacy, University of Hacettepe, Ankara, Turkey
}

(Accepted for publication 31 October 1996)

\begin{abstract}
SUMMARY
Colchicine is a microtubule disrupting agent, mostly used as treatment in various kinds of inflammatory diseases such as acute familial Mediterranean fever and Behcet's disease, as well as gout. In patients with familial Mediterranean fever treatment with colchicine induces a decline of urinary neopterin concentrations which indicates a decrease of cell-mediated immune activation. In this study, we investigated a potential effect of colchicine on the $\mathrm{T}$ cell/macrophage system in vitro. The human myelomonocytic cell line THP-1 and PBMC were treated with colchicine or the colchicine derivative, colcemide, in the presence or absence of $250 \mathrm{U} / \mathrm{ml}$ interferon-gamma (IFN- $\gamma$ ) or $10 \mu \mathrm{g} / \mathrm{ml}$ lipopolysaccharide (LPS) for $48 \mathrm{~h}$ or $96 \mathrm{~h}$. Colchicine and colcemide increased neopterin/protein production in unstimulated THP-1 cells, but no such effect was apparent in cells stimulated with IFN- $\gamma$. By contrast, when PBMC were treated with colchicine or colcemide a significant reduction in neopterin formation was evident in cells without and with prestimulation by IFN- $\gamma$ or LPS. In parallel, reduced production of IFN- $\gamma$ was observed in PBMC. These data suggest that colchicine and colcemide are able to inhibit T cell activation within the cellular immune response.
\end{abstract}

Keywords colchicine colcemide neopterin cellular immunity THP-1 cells peripheral blood mononuclear cells interferon-gamma

\section{INTRODUCTION}

Colchicine, known as an anti-inflammatory drug, binds at the $\mathrm{R}$ site on $\beta$-tubulin and causes microtubule depolymerization [1]. In this way it stops cell division in metaphase by inhibiting the movement of chromosomes within microtubules, and so can interfere with various intracellular pathways as well as secretory processes [2]. As colchicine suppresses neutrophil chemotaxis and migration of granulocytes into inflamed areas [3], it is often used for therapy of inflammatory diseases such as Behcet's disease [4], gout [3] and acute familial Mediterranean fever (FMF), in order to decrease the frequency of attacks and to prevent the development of amyloidosis in the latter condition [5-7].

Neopterin is a metabolite of guanosine triphosphate, and large amounts of it are secreted by human monocytes/macrophages upon activation by $\mathrm{T}$ cell-derived interferon-gamma (IFN- $\gamma$ ) in vitro $[8,9]$. Raised neopterin levels are commonly observed in body fluids in patients with diseases involving cellular immunity, such as allograft rejection, autoimmune diseases, infections and certain malignant disorders [10-14]. Recently, increased urinary neopterin

Correspondence: Dr Dietmar Fuchs, Institute of Medical Chemistry and Biochemistry, University of Innsbruck, Fritz-Pregl Str. 3, A-6020 Innnsbruck, Austria. excretion was described in patients with FMF during acute attacks, and neopterin levels declined rapidly when patients were treated with colchicine [15]. This observation prompted us to investigate whether colchicine had any direct influence on effector cells of the cellular immune system. For this purpose we investigated the influence of colchicine and of its close analogue, colcemide, on neopterin production by the human myelomonocytic cell line THP-1 and by PBMC.

\section{MATERIALS AND METHODS}

Cell culture

Buffy coat cells from blood of healthy donors were kindly provided by the Blood Transfusion Centre University Hospital, Innsbruck. PBMC were enriched from buffy coats by a two-step density-gradient centrifugation over Ficoll-Paque. Cells were seeded in $10 \mathrm{ml}$ RPMI 1640 medium (endotoxin concentration $<1 \mathrm{pg} / \mathrm{ml}$ ) with $10 \%(\mathrm{v} / \mathrm{v})$ heat-inactivated fetal calf serum (FCS; Biochrom, Berlin, Germany), $2 \mathrm{~mm}$ L-glutamine, $100 \mathrm{U} / \mathrm{ml}$ penicillin and $0 \cdot 1 \mathrm{ng} / \mathrm{ml}$ streptomycin, at a density of $2 \cdot 4 \times 10^{6} / \mathrm{ml}$ in 24-well plates (Falcon, Becton Dickinson, Plymouth, UK). Solutions of colchicine and colcemide in PBS (Serva, Feinbiochimica, Heidelberg, Germany) were added to the PBMC to give 
concentrations ranging from $10 \mathrm{ng} / \mathrm{ml}$ to $1 \mu \mathrm{g} / \mathrm{ml}$ in the presence or absence of $250 \mathrm{U} / \mathrm{ml}$ recombinant human IFN- $\gamma$ (specific activity $2 \times 10^{7} \mathrm{U} / \mathrm{mg}$; Bioferon, Laupheim, Germany), or $10 \mu \mathrm{g} / \mathrm{ml}$ lipopolysaccharide (LPS; phenolic extract from Escherichia coli 055 : B5; Sigma, Munich, Germany) dissolved in RPMI medium. Cells were incubated for $48 \mathrm{~h}$ and $96 \mathrm{~h}$ at $37^{\circ} \mathrm{C}$ in humidified air containing $5 \% \mathrm{CO}_{2}$. At the end of the incubation period, cells were harvested, centrifuged at $400 \mathrm{~g}$ and the supernatants were frozen at $-20^{\circ} \mathrm{C}$ or immediately used for neopterin and IFN- $\gamma$ determination.

THP-1 cells, a human myelomonocytic cell line, were obtained from the American Type Culture Collection (Rockville, MD). Cells were grown in RPMI 1640 medium (see above) and seeded at a density of $10^{6}$ cells $/ \mathrm{ml}$ in 24 -well plates. Colchicine and colcemide (see above) alone or together with $250 \mathrm{U} / \mathrm{ml} \mathrm{IFN}-\gamma$ were administered to the cells. The cells were incubated for $48 \mathrm{~h}$ at $37^{\circ} \mathrm{C}$ in the same conditions as described above for PBMC. At the end of the incubation period cells were harvested, centrifuged at $400 \mathrm{~g}$ and the supernatants were taken immediately and frozen at $-20^{\circ} \mathrm{C}$.

\section{Determination of neopterin and IFN- $\gamma$}

Neopterin was determined by a commercially available enzyme immunoassay (ELItest Neopterin; BRAHMS/Henning, Berlin, Germany) according to the manufacturer's instructions. The results are expressed as $\mathrm{pmol} / \mathrm{mg}$ protein. IFN- $\gamma$ production in PBMC was determined by an enzyme immunoassay for quantitative measurement (Interferon gamma ELISA; Endogen Inc, Cambridge, MA). Accuracy and specificity of both tests for measurements of cell culture supernatants were proved.

\section{Protein determination}

Protein contents were estimated with the BioRad protein assay according to Bradford, using freeze-dried pure bovine serum albumin (BSA) as standard [16].

\section{Statistical analysis}

Results were expressed as mean \pm s.e.m. Statistical evaluation was done using Student's $t$-test.

\section{RESULTS}

Treatment of THP-1 cells with colchicine or colcemide had an inconsistent effect on neopterin production. In unstimulated cells no change of absolute neopterin concentrations was seen after treatment with colchicum derivatives, with the exception of an increase induced with $100 \mathrm{ng} / \mathrm{ml}$ colcemide. When neopterin concentrations were expressed per mg protein, colchicine and colcemide caused an increase of neopterin release (Table 1). Divergent results were seen in IFN- $\gamma$-treated THP- 1 cells. A decrease of neopterin production was induced by both colchicum derivatives, higher concentrations leading to greater suppression of neopterin release. However, neopterin per protein content remained stable, with the exception of $10 \mathrm{ng} / \mathrm{ml}$ colcemide when the decrease remained significant (Table 1).

In PBMC, colchicine and colcemide were able to reduce neopterin production. After incubation of cells for $48 \mathrm{~h}$ a decrease of neopterin production was observed from cells stimulated with LPS or IFN- $\gamma$, but in unstimulated controls also baseline neopterin production was suppressed (Fig. 1). The effects of colchicine and colcemide were more pronounced in cells when incubation was extended to $96 \mathrm{~h}$ (Fig. 1). There were no apparent morphological abnormalities of cells seen even at the highest concentrations of colchicine and colcemide $(1000 \mathrm{ng} / \mathrm{ml})$ and no cytotoxicity was observed (Celltiter 96 Aqueous Non-Radioactive Cell Proliferation Assay; Promega, Madison, WI).

In a similar way, IFN- $\gamma$ production in cells was suppressed by the colchicum derivatives. IFN- $\gamma$ in supernatants was reduced in the presence and in the absence of LPS following incubation for $48 \mathrm{~h}$ (Table 2). Even the lowest concentration of colchicine was able to suppress spontaneous IFN- $\gamma$ production by PBMC. There was no influence of the compounds on protein concentrations in these cells.

\section{DISCUSSION}

When $\mathrm{T}$ cells are activated, several immunomodulatory cytokines such as IL-2, IL-4 and IFN- $\gamma$ are released [17]. IFN- $\gamma$ is the most important activator of macrophages to induce the production of various cytotoxic components, e.g. reactive oxygen intermediates

Table 1. Neopterin concentrations in supernatants from THP-1 cells treated with colchicine or colcemide in the presence or absence of rhu-IFN- $\gamma$ for $48 \mathrm{~h}$

\begin{tabular}{|c|c|c|c|c|}
\hline \multirow[b]{2}{*}{ Treatment } & \multicolumn{2}{|c|}{ Neopterin $(\mathrm{nmol} / l)$} & \multicolumn{2}{|c|}{ Neopterin (pmol/mg protein) } \\
\hline & None & $250 \mathrm{U} / \mathrm{ml} \mathrm{IFN}-\gamma$ & None & $250 \mathrm{U} / \mathrm{ml} \mathrm{IFN}-\gamma$ \\
\hline None & $2 \cdot 06 \pm 0.13$ & $31 \cdot 3 \pm 0 \cdot 86$ & $70 \cdot 4 \pm 4 \cdot 19$ & $1118 \pm 51 \cdot 9$ \\
\hline \multicolumn{5}{|c|}{ Colchicine $(\mathrm{ng} / \mathrm{ml})$} \\
\hline 10 & $2 \cdot 25 \pm 0 \cdot 12$ & $27 \cdot 2 \pm 1 \cdot 40^{*}$ & $83 \cdot 6 \pm 4 \cdot 67$ & $1088 \pm 34 \cdot 3$ \\
\hline 100 & $2 \cdot 06 \pm 0 \cdot 10$ & $22 \cdot 1 \pm 1 \cdot 45^{* * *}$ & $96.9 \pm 5.00 * * *$ & $1148 \pm 42 \cdot 6$ \\
\hline 1000 & $1 \cdot 94 \pm 0 \cdot 10$ & $17 \cdot 0 \pm 0 \cdot 83^{* * *}$ & $93 \cdot 1 \pm 5 \cdot 15^{* * *}$ & $1129 \pm 46 \cdot 6$ \\
\hline \multicolumn{5}{|c|}{ Colcemide $(\mathrm{ng} / \mathrm{ml})$} \\
\hline 10 & $2 \cdot 48 \pm 0 \cdot 30$ & $25 \cdot 9 \pm 0.91 * *$ & $64 \cdot 1 \pm 4 \cdot 44$ & $888 \pm 26 \cdot 7 * * *$ \\
\hline 100 & $2 \cdot 74 \pm 0 \cdot 20^{*}$ & $24 \cdot 7 \pm 1 \cdot 03^{* *}$ & $92 \cdot 7 \pm 4.95^{* *}$ & $1181 \pm 40 \cdot 3$ \\
\hline 1000 & $2 \cdot 02 \pm 0 \cdot 16$ & $17 \cdot 0 \pm 0 \cdot 73^{* *}$ & $84 \cdot 2 \pm 5 \cdot 34^{*}$ & $1138 \pm 58 \cdot 9$ \\
\hline
\end{tabular}

Results (mean \pm s.e.m.) are representative of three different experiments run in triplicates. $* P<0 \cdot 05 ; * * P<0 \cdot 01$; $* * * P<0 \cdot 001$. 

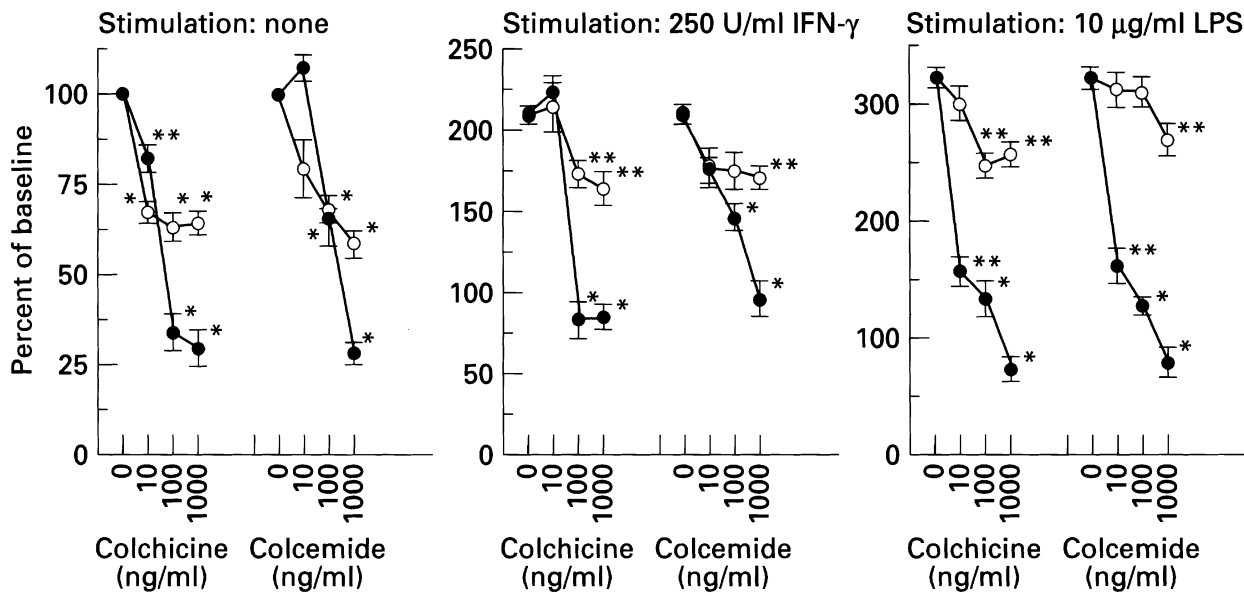

Fig. 1. Neopterin in percentage of baseline (untreated cells at $48 \mathrm{~h}, 261 \pm 16 \mathrm{pmol} / \mathrm{mg}$ protein; and $96 \mathrm{~h}, 1596 \pm 63 \mathrm{pmol} / \mathrm{mg}$ protein, respectively) in supernatants from PBMC following treatment with colchicine or colcemide after incubation for $48 \mathrm{~h}(\mathrm{O})$ and $96 \mathrm{~h}(\bullet)$. Results represent mean values \pm s.e.m. of three different experiments run in triplicates. $* * P<0.05 ; * P<0.01$.

[18], and it also induces a number of cytokines which further contribute to maintenance of the immunoregulatory cascade $[17,19,20]$. In turn, IFN- $\gamma$ stimulates neopterin production in human monocytes/macrophages, and the neopterin concentration in body fluids is a sensitive indicator of the activation of cellmediated immunity $[9,10]$.

The present study has demonstrated an inhibitory effect of colchicine and colcemide on neopterin production and release in PBMC. Colchicine or colcemide also decreased absolute concentrations of neopterin in THP- 1 cells stimulated with IFN- $\gamma$, but in this case the effect disappeared almost completely if concentrations were related to protein contents. Moreover, colchicum derivatives were even capable of increasing neopterin/protein concentrations in unstimulated THP-1 cells. Similarly, Ferrua et al. have found that these drugs can induce production of IL-1 $\beta$ in unstimulated THP-1 cells [21]. Notably, no correction for protein content was calculated by Ferrua et al., and the concentrations applied were higher than those in our experiments, but in general these and our results support the notion that there exists some stimulatory capacity of colchicum derivatives on resting monocytic cells.

Table 2. Production of IFN- $\gamma$ by PBMC treated with colchicine or colcemide in the presence or absence of $10 \mu \mathrm{g} / \mathrm{ml}$ lipopolysaccharide (LPS) for $48 \mathrm{~h}$

\begin{tabular}{lcc}
\hline $\mathrm{ng} / \mathrm{ml}$ & $\begin{array}{c}\text { None } \\
\mathrm{pg} / \mathrm{mg} \text { protein }\end{array}$ & $\begin{array}{c}\text { Stimulated with LPS } \\
\mathrm{pg} / \mathrm{mg} \text { protein }\end{array}$ \\
\hline None & $20 \cdot 7 \pm 1 \cdot 0$ & $39 \cdot 5 \pm 5 \cdot 3$ \\
Colchicine & & \\
10 & $6 \cdot 9 \pm 0 \cdot 7 * *$ & $32 \cdot 9 \pm 1 \cdot 8$ \\
100 & $6 \cdot 3 \pm 0 \cdot 7^{* *}$ & $8 \cdot 9 \pm 0 \cdot 9^{*}$ \\
1000 & $5 \cdot 2 \pm 0 \cdot 3^{* * *}$ & $6 \cdot 7 \pm 0 \cdot 3^{*}$ \\
Colcemide & & \\
1000 & $4 \cdot 3 \pm 0 \cdot 4^{* * *}$ & $5 \cdot 3 \pm 0 \cdot 2^{*}$ \\
\hline
\end{tabular}

Values are expressed as mean \pm s.e.m. $\quad(n=3)$. $* P<0.05 ; * * P<0.01$; *** $P<0.001$.
There was a decline in neopterin production when PBMC were treated with colchicum derivatives, even in the absence of prestimulation of cells by IFN- $\gamma$ or LPS. Because IFN- $\gamma$ production in PBMC was also suppressed by colchicine and colcemide, the data suggest that the drugs can inhibit $\mathrm{T}$ cell activation and that the effects of those compounds on neopterin production by PBMC are merely due to their interaction with $\mathrm{T}$ cells rather than with monocytes/macrophages. It is well established that neopterin secretion is directly related to the exposure to IFN- $\gamma[8,9,22,23]$, and a suppression of IFN- $\gamma$ production by PBMC would in turn decrease neopterin production. In our study, the total effect of colchicum derivatives on the mixed population of PBMC is suppressive with respect to neopterin production rates.

Thus far, monocytes/macrophages are considered to be the sole relevant source of neopterin formation [10]. Earlier we have demonstrated that the human myelomonocytic cell line THP-1 behaves similarly to human monocytes/macrophages isolated from peripheral blood with respect to the conditions necessary for neopterin production [22]. Certainly the tumour cell line THP-1 cannot be regarded as functionally equivalent to mature peripheral blood monocytes, but the inhibitory capacity of colchicum derivatives on IFN- $\gamma$ production by PBMC seems much more drastic than their eventual stimulatory effect on monocytic cells.

When PBMC were stimulated with LPS or IFN- $\gamma$ for $48 \mathrm{~h}$ and treated with colchicine or colcemide, there was a decrease in neopterin production, and the effect was much more pronounced when cells were stimulated for $96 \mathrm{~h}$. The data agree with reduced neopterin levels observed in FMF patients under treatment with colchicine [15], and may indicate that these agents interfere with the activation of T lymphocytes and reduce production of IFN- $\gamma$ also in the in vivo situation. This view is supported by earlier data obtained from mixed lymphocyte culture experiments in rats, in which a significant reduction of lymphocytic proliferation and enhanced survival of renal allografts were seen during long-term use of colchicine [24]. Also in humans colchicine was found to be able to inhibit cytokine production.

Colchicine was found to reduce the increased production of IL-1 in patients with primary biliary cirrhosis as well as to inhibit fibroblast proliferation [25]. It has to be kept in mind that the concentrations used for treatment are much lower than those tested 
in the in vitro experiments, but treatment of FMF patients with colchicine resulted in decreasing suppressor $\mathrm{T}$ cell counts and increasing natural killer (NK) cell numbers, and it reduced IL-2 production [26].

We conclude that colchicine and its analogue colcemide inhibit IFN- $\gamma$ and neopterin production in PBMC. A role for colchicine in the regulation of the immune system seems to be evident.

\section{ACKNOWLEDGMENTS}

This work was financially supported by the Austrian funds 'Zur Förderung der wissenschaftlichen Forschung', P10776. Z.Z.A. was supported by a grant from the Austrian Ministry of Science and Research.

\section{REFERENCES}

1 Burns RG. Analysis of colchicine-binding site of $\beta$-tubulin. FEBS Lett 1992; 297:20-28.

2 Stryer L. Biochemistry, 2th edn. San Francisco: Freeman and Co., 1981.

3 Goodman AG, Goodman LS, Rall TW et al. Goodman and Gilman's the pharmacological basis of therapeutics, 7 th edn. New York: McMillan, 1986:708-15.

4 Hayasaka S, Kawamoto K, Noda S et al. Visual prognosis in patients with Behcet's disease receiving colchicine, systemic corticosteroid or cyclosporin. Ophtalmologica 1994; 208:210-3.

5 Dinarello CA, Wolff SM, Goldfinger SE et al. Colchicine therapy for familial Mediterranean fever: a double-blind trial. N Engl J Med 1974; 291:34-37.

6 Livneh A, Zemer D, Langevitz P, Laor A, Schar E, Pras M. Colchicine treatment of AA amyloidosis of familial Mediterranean fever. Arthritis Rheum 1994; 37:1804-11.

7 Zemer D, Pras M, Sohar E et al. Colchicine in the presentation and treatment of the amyloidosis of familial Mediterranean fever. NEJM 1986; 314:100-5.

8 Huber C, Fuchs D, Hausen A et al. Pteridines as a new marker to detect human T-cells activated by allogeneic or modified self major histocompatability complex (MHC) determinants. J Immunol 1983; 130: $1047-50$

9 Huber C, Batchelor R, Fuchs D et al. Immune response associated production of neopterin release from macrophages primarily under control of interferon gamma. J Exp Med 1984; 165:310-6.

10 Fuchs D, Hausen A, Reibnegger G, Werner ER, Dierich MP, Wachter H. Neopterin as a marker for activated cell-mediated immunity: application in HIV infection. Immunol Today 1988; 9:150-5.
11 Reibnegger G, Fuchs D, Fuith LC et al. Neopterin as a marker for activated cell-mediated immunity: application in malignant disease. Cancer Detect Prevent 1991; 15:483-90.

12 Fuith LC, Czarnecki M, Fuchs D et al. Determination of neopterin, a marker of cell-mediated immunity in gynecologic oncology. Int J FetoMaternal Med 1993; 6:235-8.

13 Reibnegger G, Aichberger C, Fuchs D et al. Posttransplant neopterin excretion in renal allograft recipients: a reliable diagnostic aid for acute rejection and a predictive marker of long-term graft survival. Transplantation 1991; 52:58-63.

14 Fuchs D, Weiss G, Reibnegger G, Wachter H. The role of neopterin as a monitor of cellular immune activation in transplantation, inflammatory, infectious and malignant diseases. Crit Rev Clin Lab Sci 1992; 29:307-41.

15 Altindag ZZ, Sahin G, Isimer A, Duru S, Kadayifci A, Simsek H. Urinary neopterin levels in familial Mediterranean fever. Pteridines 1995; 6:17-18.

16 Bradford MM. A rapid and sensitive method for the quantitation of microgram quantities of protein utilizing the principle of protein dye binding. Anal Biochem 1976; 72:248-54.

17 Dinarello CA, Mier JW. Current concepts: lymphokines. N Engl J Med 1987; 8:940-1.

18 Philiph R, Epstein LB. Tumor necrosis factor as immunomodulator and mediator of monocyte cytotoxicity induced by itself, gamma-interferon and interleukin 1. Nature 1986; 323:86-89.

19 Hermann F, Cannistra SA, Griffin JD. T cell-monocyte interactions in the production of humoral factors regulating human granulopoiesis in vitro. J Immunol 1986; 136:2856-61.

20 Metcalf D. Haemopoietic growth factors 1. Lancet 1989; i:825-7.

21 Ferrua B, Manie S, Doglio A et al. Stimulation of human interleukin 1 production and specific mRNA expression by microtubule disrupting drugs. Cell Immunol 1990; 131:391-7.

22 Werner-Felmayer G, Werner ER, Fuchs D et al. Neopterin formation and tryptophan degradation by a human myelomonocytic cell line (THP-1) upon cytokine treatment. Cancer Res 1990; 50:2863-7.

23 Wachter H, Fuchs D, Hausen A et al. Neopterin as marker for activation of cellular immunity: immunologic basis and clinical application. Adv Clin Chem 1989; 27:81-141.

24 Ostermann D, Perico N, Imberti O. Colchicine allows prolonged survival of highly reactive renal allograft in the rat. J Am Soc Nephrol 1993; 4:1294-9.

25 Kershenobich D, Rojkind M, Quiroga A et al. Effect of colchicine on lymphocyte and monocyte function and its relation to fibroblast proliferation in primary biliary cirrhosis. Hepatology 1990; 11:205-9.

26 Melamed A, Cabili S, Zakuth V et al. The immune regulation in familial Mediterranean fever (FMF). J Clin Lab Immunol 1988; 26:125-8. 